sixteenth centuries A.D. Guided by theories of traditional Chinese type, not of course the same as those of modern science, and using urine in large quantities (up to 300 gallons) as their starting-point, they succeeded in preparing mixtures of androgens and ostrogens in rolativoly purified form, and utilizing them in medicine for many hypogonadic conditions. The classical discovery of Aschheim and Zondek in 1927 that pregnancy urine contains large quantities of certain steroid sex hormones ${ }^{1}$, and the subsequent recovery of these and others from other urinary sources, was thus strangoly anticipated.

All the methods (we have translated six of them) start with largo amounts of urine (as if on a modern pharmaceutical manufacturing scale), from adults or adolescents of each sex. The simplest, possibly the oldest, took the whole mass obtained by evaporating to dryness, including the steroid glucuronides and sulphates with much elso; but most of the mothods embodied various precipitations to obtain a colourless and odourless product. One used calcium sulphate, which would have assisted protein precipitation and therefore that of the conjugates also. Another made use of the saponins from the soap-bean tree, Gleditschia sinensis ${ }^{2}$, the bean jùice being added to the urine at the rate of one bowlful for every tub. The precipitate was afterwards extracted with boiling water, so that some steroids carried down on the protein were probably releascd as it denatured, while those combined with the saponins remained insoluble. Without ad hoc experiments, which it would indeed be interesting to carry out, one cannot say which steroid hormones could have been thus separated; but the quasi-empirical anticipation of the classical discovery of the digitonin precipitation of cholesterol by Windaus in 1909 is extraordinary $^{3}$. Besides the vegetable protein added in the soap-bean juice, it is highly probable that other proteins were usually presont, sinco in medieval times proteinuria. would bo expected among some of the numerous donors, and this would aid the precipitation of tho steroid conjugates.

In nearly all the methods the process ends by a sublimation. A.t first this seemed difficult to understand, but in fact the urinary steroid sex-hormones do sublime unchanged in air between about $140^{\circ} \mathrm{C}$ and $280^{\circ} \mathrm{C}$, there being considerable differences in sublimation temperature between them ${ }^{4}$. The deseription of the sublimation vessels in tho texts is quite clear and unmis- takable. Small earthenware pots were used with carefully luted covers, and great attention was paid to the degrce and duration of heating. Chineso alchemists had been perfecting sublimation and distillation techniques since the second century B.C.; the iatro-chemists could therefore now prepare a rathor purified mixture, as is indicatod by the descriptions of the material as white, crystalline, glittering and lustrous or pearly like translucent jade. Finally, the sublimate was often emulsified with milk fat. Of course the end-products were complex mixtures of many different compounds, depending on the fractionation procedures used and on the original source material; but their pharmaceutical efficacy is vouched for by the descriptions of the conditions for which they were prescribed.

The six methods mentioned date from the eleventh to the sixteenth centuries A.D., and are preserved in Chapter 52 of the great Pharmacopœia of 1596 (Pên Tshao Kang $M u)$ by $\mathrm{Li}$ Shih-Chen from books no longer extant, or extremely rare. The oldest is the Ching Yen Fang (Tried and 'Tested P'rescriptions) by Chang Shêng-Tao, dating from 1025, and quoted already in the Chêng Lei Pên Tshao of 1249. Then from the early years of the twelfth century A.D. we have two further descriptions in the Shui Yün Lu (Water and Clouds Record), written by a famous scholar, Yeh Mêng-Tê (1077-1148). Another book of the same period, the So Sui $L u$, by an unknown author, theorizes about these preparations. The rest are in three books of the Ming period. If one asks how these medieval iatro-chemists could have been led to their urinary preparations, the answer surely is that classical Chinese medical and physiological theory envisaged a constant interaction among the organs of the body mediated through the circulating blood. Since the urine was considered as "of the same category as" (thung lei) the blood, then the virtues emanating from the organs might perhaps be found in it also.

The full material will appear in Medical History. For helpful discussions in its evaluation we thank Dr. Roger Short, Prof. H. Brouer and Dr. Hal Dixon.

\footnotetext{
Klin. Wochenschr., 6, 1322 (1927).

${ }^{2}$ See Needham and Iu, J. Hist. Med. and Allied Sci.,17, 429 (1962) (abridged in Health Educ. J., i7, 170; 1959).

s Ber. deutsch. Chem. Gesellsch., 42, 238 (1909).

Breuer, H., and Kassau, E., Proc. First Intern. Congr. Endocrin., Sect. 11d, No. 561, Copenhagen (1960). Kassau, E., Deutsche Apotheker Zeitung, $100,1102(1960)$.
}

\title{
OBITUARY
}

\section{Dr. William C. Hayes}

Dr. Whlitam Christopher Hayes, curator since 1952 of the Egyptian Department of the U.S. Metropolitan Museum of Art, who died suddenly on July 10, was one of the outstanding Egyptologists of his generation, being equally celebrated as a historian, philologist ard archæologist.

He was born at Hempstead, Long Island, on March 21, 1903, of an English fathor and of a mother who came of a prominent Philadelphia family. He was oducated at St. George's School, Newport, where he won a medal for classics and graduatod in 1924 at Princeton Univorsity. Here, two years lator, he took his master's degree, having won a Carnegie scholarship for the study of modieval and Byzantine art, an interest which is refloctod in his early paper on an engraved glass bowl in the Vatican Library. On being appointed to the staff of the Metropolitan Museum Egyptian Expedition in 1928, however, ho henceforth devoted his talonts to the study and elucidation. of Ancient Egypt.

Hayes came comparatively late to his subject, and the only formal training in Ancient Egyptian that he recoived was with Sir Alan Gardiner at Oxford, where on occasions he stayed on his way home after the season's excavations. Novertheless, he producod in 1935 his Royal Sarcophagi of the XVIIIth Dynasty, a remarkable and unique work in which his early discipline as an art-historian as well as his Egyptological learning was brought to bear on the study of a whole group of monuments, and succeeded among other things in solving some long-standing problems concorning the history of the Dynasty. This modol publication, for which he received a Ph.D. from Princeton, was the first of a number of books and articles all characterized by the impact of a well-balanced and clear-sighted judgment and written by a mastor of Fnglish prose. His publication of a hieratic papyrus in the Brooklyn Museum, which ho assembled from many bundreds of fragmonts, showed how an unpromising text could be transformed in his hands into a wealth of information on late Middle Kingdom social lifo and administration. His mose rocent works were four fasciclos of tho revised Cambridge Ancient History.

In Egypt ho had largely been concerned with the reconstruction of the smashed statues of Queen Hatshepsut found by the Americans scattered in a quarry near her 
great temple at Deir el-Bahri and over a number of Europoan museums. He also, with Lansing, excavatod the tomb of the parents of Sennemut, but whon the Expedition closed jts operations in Egypt in 1936, he returned to New York as an assistant curator in tho Motropolitan Museum. Ho had spent much of his spare time messing about in boats off the New England coast, and when the U.S. called up reservos in 1941 ho joined the Navy, rising to the rank of lieutenant-commander and. boing decorated for gallantry in the Pacific theatre of the
War. He returned to the Museum in 1945 as associate curator. In 1959 he was appointed Amorican representative on the International Committeo for the Preservation of the Nubian Monumonts. He has left a widow and two sons.

A man of groat integrity, quiet strength and a ponetrating wit, Bill Hayes earned the respect and indeed the affection of all his colleaguos on both sides of the Atlantic. The loss to Egyptology by his unexpected doath with much of his work still in draft form is a grievous one.

\section{NEWS and VIEWS}

\section{The Royal Society: Officers for 1964}

Aт the Anniversary Meeting held on November 30, Sir Howard Florey, provost of the Queen's College, Oxford, and formerly professor of pathology in the University of Oxford, was re-elected president of the Royal Society.

The other officers re-elected for the ensuing year were: Treasurer, Lord Fleck, formerly chairman of Imperial Chemical Industries, Ltd.; Physical Secretary, Sir William Hodge, Master of Pembroke Collego and Lowndean professor of astronomy and geometry in the University of Cambridge; Foreign Secretary, Sir Patrick Linstead, rector of the Imperial College of Science and Technology. Prof. A. A. Miles, director of the Listor Instituto and professor of experimental pathology in the University of London, was eleeted biological secrotary.

Tho other members of Council elected (or re-elected, marked *) were: Prof. P. M. S. Blackett, profossor of physies in the Imperial Collego of Science and Technology; Prof. A. R. Clapham, professor of botany in the University of Sheffield; Prof. A. H. Cottrell, Goldsmiths' professor of metallurgy in the University of Cambridge; Prof. C. A. Coulson, Rouse Ball professor of mathematics in the University of Oxford; *Prof. E. F. Gale, professor of chemical microbiology in the University of Cambridge; *Prof. E. L. Hirst, Forbes professor of organic chomistry in the University of Edinburgh; Prof. B. Katz, professor of biophysies in University College (University of London); *Prof. D. Lewis, Quain professor of botany in University College (University of London); Sir Bernard Lovell, professor of radio astronomy in the University of Manchester and director of the Nuffield Radio Astronomy Laboratories, Jodrell Bank; *Dr. P. B. Medawar, director of tho National Institute for Medical Research; *Prof. W. T. J. Morgan, deputy director of the Lister Institute and professor of biochemistry in the University of London; Prof. A. B. Pippard, John Humphrey Plummer professor of physies in the University of Cambridge; Prof. J. W. S. Pringle, Linacre professor of zoology in the University of Oxford; Sir Ewart Smith, formerly a deputy chairman. of Imperial Chemical Industries, Ltd.; Prof. J. H. Taylor, professor of geology in King's College (University of London); *Dr. H. W. Thompson, university reader in infra-red spectroscopy, Oxford.

(Publication of the prosidential addross and award of medals at the anniversary meeting of the Royal Society has been deferred until the issue of Decomber 28.)

\section{Chief of Electrical Instruments Section at the National \\ Bureau of Standards: Mr. F. L. Hermach}

Mr. F. L. Hermacir has been appointed chief of the Electrical Instruments Section in the Electricity Division at the National Bureau of Standards, U.S. Department of Commerce. Mr. Hormach replaces Dr. F. M. Defandorf, who died in August. Born in Bridgeport, Connecticut, in 1917, Mr. Hermach has been with the Bureau since 1939. $\mathrm{He}$ received a B.E.E. in 1943 from George Washington University. In 1954, he was the recipient of the Commerce Department's Silver Medal for Meritorious Service for his contribution to the standardization of electrical measurements in the development of a highly accurate transfor instrument for measurements. In that same year, Mr. Hermach received a Superior Performance Award from the National Bureau of Standards. As chicf of the Eloctrical Instruments Section, Mr. Hermach will be concerned with the dissemination of values for a.e. and d.c. standards for use in measuring electric current, voltage, power, and energy from very low to very high values. He will also be responsible for miscellaneous electrical measurements noeded for engineering purposes.

\section{Chemical Engineering at Monash University :}

Prof. O. E. Potter

DR. O. E. PotTer, at present reader-in-charge of the Department of Chemical Engineering at the Univorsity of Melbourne, has been appointed to the foundation chair of chemical engineering at Monash University. Aftor graduating with honours in applied scionco from Queensland Univorsity, and comploting a Master's degree, Dr. Potter proceeded on a Queensland Foundation travelling scholarship to University College, London, whore he road history and philosophy of science. Later he became a lecturer in chemical engineering at the Manchester Collego of Science and Technology in the Univorsity of Manches. ter, where ho also completed a Ph.D. on a number of fundamental aspects of liquid-liquid reactions. In 1960, Dr. Potter was appointed reader-in-charge of tho Department of Chemical Fngineering in the University of Melbourne and head of the Department in the Royal Melbourne Institute of Technology. At that time the Institute had a very limited staff, while there was no permanent University staff. Through Dr. Pottor's very considerable personal efforts, staff was obtained for both Departments, laboratories were vitalized and student numbers began to increase. Postgraduato research was started, so that after only three years there are twelve full-time students for higher degrees. Dr. Potter has wide research interests in fluidization invostigations, mass transfer phenomona and technical kinotics. Ho has published a number of scientific papers in these fields and has contributed the section on tochnical kinetics in the Chemical Engineering Practice sorios.

Physiology in the University of Malaya, Kuala Lumpur: Prof. G. Barber-Riley

Dr. G. Barber-Riley, lecturer in physiology in the University of Cape Town and formerly lecturor in physiology in the University of Liverpool, has been appointed the first professor of physiology in the University of Malaya, Kuala Lumpur. Dr. Barber-Riley was born in 1920. Ho was educated at Wallasey Grammar School. Between 1941 and 1946 he served with the R.A.F.V.R., holding the rank of warrant officer, with the duties of observer, and later navigator and wireless operator. He made many sorties over Europe, including low-levol flights in Mosquitoes. After tho War he first studied in the University of Manchester (1946-48) and then became a medical student in the University of Livorpool, graduating M.B., Ch.B. in 1958. He had interealated a year of 